\begin{tabular}{|c|c|c|}
\hline$W_{\text {INESEG }}$ & $\begin{array}{l}\text { INTERNATIONAL } \\
\text { ENGINEERING, } \\
\text { SCIENCE AND } \\
\text { EDUCATION } \\
\text { GROUP }\end{array}$ & $\begin{array}{l}\text { Middle East Journal of Science } \\
\text { (2018) 4(2): } 58 \text { - } 65 \\
\text { Published online December 26, } 2018 \quad \text { (http://dergipark.gov.tr/mejs) } \\
\text { doi: } 10.23884 / \text { mejs.2018.4.2.01 } \\
\text { e-ISSN 2618-6136 } \\
\text { Received: June 25, } 2018 \quad \text { Accepted: July 7, } 2018 \\
\text { Submission Type: Research Article }\end{array}$ \\
\hline
\end{tabular}

\title{
RESEARCH OF LAVENDER PLANT PROPAGATION IN THE PROVINCE OF DIYARBAKIR
}

\section{Medet Korkunc}

Dicle University, Diyarbakır Vocational Agriculture School, Seed Program, Diyarbakır, Turkey

*Corresponding author; medet.korkunc@ dicle.edu.tr

\begin{abstract}
Lavender flowers are from the family Ballibagiller (Labiatae) and grow in North westand South west Anatolia Between June and August, blue or purple flowers open, 20-60 cm in length, aromatic smelling, perennial, herbaceous or playful plants. More widespread in western regions where marine climate is present.There are two species that grow in Turkey. These are Lavandula $x$ intermediave and Lavandula angustifolia Lavender is an important perfume, cosmetics and medicine plant cultured in the world due to its high content and high quality oil content The purpose of our research is to cultivate this plant and to revealits medicinal and aromatic properties. In the study, preseedling stems were prepared from 'Raya', 'Silver' and 'Vera' lavander varieties of Lavandula angustifolia species as field materia land 'Giant, Hid, cote', 'Dutch' and 'Supera' lavandin varieties of Lavandula x intermedia species and selected the 'Super A' lavandin variety of Lavandula x intermedia that could be adapted in Diyarbakir conditions. Production and reproduction of lavender plant as in other aromatic plants arecarried out in two main ways, generative and vegetative. However, because of the in fertility of the 'Super A' lavandin variety of Lavandula x intermedia crewand the lack of seeds, vegetative propagation ands hoot steels were used. The seedlings of the "Super a" lavandin of the Lavandula $x$ intermedia line were placed $1 \mathrm{~m}$ abovetherowand $3 \mathrm{~m}$ apart from the row, in the experimental area of the Dicle University MedicalandAromatic Plants Application and Research Center 7 days a week 6-7 April 2017. A total of 2100 seedlings were planted in the trial area and later juveniles were given. The maintenance and irrigation works of the seedling lites were carried out regularly at the trial and drip irrigation system was used in the study. At the beginning of June some of the seedling lites were found dead. The survival of the remaining seedling lites continued and the adaptation rate was $63 \%$ Flowering The flowers were harvested 3 times betweenJ une and October, which began in June. In December, the shoot steels were rooted in the serpentine and replicated in the plants we obtained for seedling formation At the and of this study; 21-33 cm long plants were obtained, These results formed the opinion in light of lavender farm will be made in Diyarbakir in Turkey. This year we will also work on the determination of the medical and aromatic contents of plant materials obtained from our work.
\end{abstract}

Key Words: Lavender, seedling, steel and planting 


\section{Introduction}

In recent years, the demand for herbal medicines for treatment, the perfumery of fragrant plants, the formation of the main raw materials of the food and cosmetics industry and the emergence of new areas of use have increased the demand for medical and aromatic plants. Raw materials obtained from these plants have recently been used in the food industry, especially in the industrial sectors such as paint, ornaments, and they have begun to spread [15].

Lavanta is most prevalent in southern Europe and in neighboring countries of North Africa [8], especially in the Mediterranean and Balkan countries. France, Bulgaria, Spain, Italy, Greece, England, USA, Russia, Austria and North Africa [22].

Lamiaceae (Labiatae) family is represented in the world with about 224 genera and 5600 species, Turkey constitutes one of the Lamiaceae family of genes important for the center. Additionally, this family of 45 genera in Turkey, there are 565 species and 735 taxa [12]. The important species of this family, which are medicinal and aromatic, are Mintha, Thymus, Origanum, Sage, Sideritis, Melissa Rosmarinus and Lavandula [14].

The real lavender plant is a semi-annual plant, a perennial plant. As you get older, a large number of branches are formed, starting from the bottom upwards, with an average length of $40-60 \mathrm{~cm}$ and a maximum length of $1.2 \mathrm{~m}$. There are mutually $2-5 \mathrm{~cm}$ long, short-stemmed, greyish-green leaves in the dahlia, and the flowers are gathered at the ends of the stems $15-20 \mathrm{~cm}$ long resembling the head of the head. There are an average of 6 flower clusters in each spike and 5-20 flowers in each cluster. The flower clusters are protected by two sheets facing each other. The actual lavender flowers, which are very short stalks, are wrapped in gray-blue color, with straight, bright, non-hairy 4-6 mm long dish leaves. The leaves of the dish wrap around like a flower pipe and end with 4 small pointed teeth at the end. There are four male organs among the petals that vary from violet to violet [13-17].

The real lavender is rich in limestone, and has developed very well in dry and calcareous soils with a $\mathrm{pH}$ of 5.8-8.5. It produces less volatile oil in soils that are extremely humid, have a high base water and a high proportion of organic matter. It is originated from the Mediterranean and is very resistant to stasis and temperature. However, the resistance to cold is not as high as the resistance to stasis. Cold weather can sometimes be seen in regions where winter is very hard. The southern-facing, dominant winds are less cold-covered in sloping areas. However, in sloping areas, the direction of planting is planned to be steep [4-16].

The most Lavander in the World (L. angustifolia Mill.) and lavandin (L.x intermedia Emeric ex Loisel.) agricultural varieties into their species maintained, while in Turkey in economic terms only lavandin in Isparta (L.x had intermedia. Super A) culture is done. Lavender has adapted very well to this irrigation, barren and sloppy land. [7].

There is intermedia L. grown in Isparta. Fresh lavender with an average of 500-750 kg / da is taken from the Supera lavandin variety. After drying, $100-150 \mathrm{~kg} / \mathrm{da}$ dry flower yield is obtained with the sap leaves. When fresh bunch of $5 \mathrm{~kg}$ stems are dried, about $1 \mathrm{~kg}$ of stemless dry lavender flowers are produced. $65 \%$ of the dried stem flower bundles are sap, 35\% are fruit [5].

Production and multiplication of lavender plant as it is in other aromatic plants is done in two main ways, generative and vegetative. Some types of lavender are generative only, some types are vegetatively, and some types of lavender and varieties of lavender can be reproduced more easily and quickly in both ways. [3-6]. 
In medicinal and aromatic plants, the active substances vary depending on the genotype and the environment. The characteristics of the plants such as metobolite extractions, volatile oil composition, volatile oil content, age and dry drug yield may vary. Tissue culture technique microcultivation method has the same genetic structure to eliminate the negative aspects of seed and steel production, allowing vegetative propagation of seedlings quickly and in large quantities. In addition, micro-production techniques in medical and aromatic plants, which are particularly sensitive to environmental conditions, can be considered as an alternative form of production to traditional production methods [11-19-20].

In addition, in order to obtain a large number of seedlings, it is necessary to encounter difficulties in obtaining suitable steel, and a large rootstock garden to be taken of the steel. In seed production, development is generally slow, seed germination problems can occur, and there are large variations in morphological and volatile oil composition due to foreign pollination [18].

Since lavender is a perennial plant, it is economically beneficial for at least 15 years from the same lavender plantation. Lavender steels are mostly planted in early spring or early summer [10].

Lavender plants begin budding in June and bloom in July. Flowering time varies depending on species and variety, climate and soil conditions, altitude and region. Harvest time in lavandula is very effective on the yield and quality of essential oils [21].

The increase in interest in lavender farming in recent years has increased the importance of scientific research on this plant's advanced breeding techniques and made significant improvements. Studies on the propagation of the steel have gained tremendous value, especially in species with seed multiplication problems. Smoking irrigation of Isparta province, arid areas and slopes to extremely good harmony lavender, which provides a dry crops, if it is determined varieties that produce volatile fatty marketable quality in the world and then can be distributed determined to rapidly reproducing manufacturers seedlings of these varieties, lavender and Isparta big win for both Turkey's economy [2].

The purpose of this research; lavender cultivated economically in Turkey made only in Isparta region for higher flower yield and high volatile oil quality (containing high proportions of linalyl acetate and low in camphor) has, adaptability high lavandin varieties Diyarbakir and to provide the local and this kind of agricultural and to determine the technological properties, to adapt to in vivo conditions of lavender cultivar with limited possibilities of production with seeds and sometimes even impossible, and to investigate possibilities of propagation by means of steel, to produce a large number of healthy seedlings from mature lavender plants.

\section{Material and Method}

\subsection{Research Place and Year}

Field experiment, Dicle University Medical and Aromatic Plants Application and Research Center between April 6, 2017-2018; The sera experiment was carried out in 2018 in the Medical and Aromatic Plants Application and Research Center.

\subsection{Plant Species Used in Research}

In the study, "Supera" from Egridir Fruit Research Center located in Eğridir district of Isparta province was used as material by taking fidelity of variety. This variety is one of the most important 
varieties used in the production of commercial lavender in the world. The location obtained with the lavandin type used in the experiment is given in Table 1.

Table 1. The type of lavandin used in the research and its origin

\begin{tabular}{|l|l|l|l|}
\hline Type & Variety name & Trade name & Origin(where available \\
\hline L.x intermedia & Super A & Lavandin & Türkiye-Isparta \\
\hline
\end{tabular}

The characteristics of variety used in the research are briefly mentioned below by making use of "Anonymous [1]".

\subsection{Soil preparation}

Dicle University Medical and Aromatic Plants Application and Research Center area on April 6, $2017140 \times 30 \mathrm{~m}$ (4.2 decares) area is determined. Immediately prior to planting, fertilization was carried out in such a way as to be $6 \mathrm{~kg} \mathrm{~N}, 6 \mathrm{~kg}$ P2O5 per decare, which is widely applied in the area. Land was cultivated before cultivation. Lines were then opened with row openers to form rows and rows of $3 \mathrm{~m}$ and a drip irrigation system was established after the soil was left to rest. The struggle with weeds was carried out by rotating them with a rotator, and the rows were processed with anchors.

Table 2. Monthly climate data for the period of the experiment *

\begin{tabular}{|c|c|c|c|c|c|c|c|c|c|}
\hline \multirow{2}{*}{ MONTHS } & \multicolumn{3}{|c|}{ TEMPERATURE } & \multicolumn{3}{c|}{ RAINS } & \multicolumn{3}{c|}{ HUMIDITY(\%) } \\
\cline { 2 - 11 } & HIGH & AVG & LOW & HIGH & AVG & LOW & HIGH & AVG & LOW \\
\hline JANUARY & 12 & 7 & -4 & 4,1 & 0,5 & 0 & 100 & 71 & 13 \\
\hline FEBRUARY & 18 & 8 & -2 & 0,5 & 0 & 0 & 100 & 62,3 & 6 \\
\hline MARCH & 20 & 9,16 & -1 & 10,9 & 1,8 & 0 & 100 & 68,48 & 14 \\
\hline APRIL & 26 & 12,26 & 0 & 16 & 1,8 & 0 & 100 & 67,63 & 14 \\
\hline MAY & 33 & 18,41 & 7 & 9,9 & 0,8 & 0 & 100 & 57,03 & 7 \\
\hline JUNE & 42 & 25,7 & 12 & 3 & 0,1 & 0 & 77 & 29,2 & 4 \\
\hline JULY & 43 & 31,22 & 19 & 0 & 0 & 0 & 49 & 18,67 & 4 \\
\hline AUGUST & 44 & 30,06 & 17 & 0 & 0 & 0 & 52 & 22,06 & 4 \\
\hline SEPTEMBER & 40 & 26,26 & 13 & 0 & 0 & 0 & 58 & 21,36 & 4 \\
\hline OCTOBER & 29 & 17,09 & 6 & 21,1 & 1 & 0 & 100 & 38,09 & 7 \\
\hline NOVEMBER & 21 & 10,06 & -2 & 5,1 & 0,3 & 0 & 100 & 66,66 & 20 \\
\hline DECEMBER & 17 & 6 & -5 & 2 & 0,2 & 0 & 100 & 73,45 & 16 \\
\hline
\end{tabular}

*Diyarbakır Regional Directorate of Meteorology 2017 records

\subsection{Preservation of seedlings}

In the study, the roots of the 'Supera' lavandin from Eğridir Fruit Research Center located in the district of Eğridir in Isparta province were kept in water for 1 day before fiddling and then planted. 


\subsection{Seedlings planting}

A total of 1552 seedlings were planted in the previously prepared $140 \times 30 \mathrm{~m}$ (4.2 decare) area of the 'Super A' lavandin, previously moistened with roots in water. Then, after the sewing operation was finished, the drip irrigation system was opened and all the seedlins life waters were given.

There is intermedia L.x. Super A; In June and July, long flowers are blossoming, bluish purple color, flower stalks are long, sharp fragrant, leaves are silvery green, frequently arranged, branches are very long and semi-slanting up to $90 \mathrm{~cm}$, volatile oil and flower is high, used as ornamental plant a kind of lavandin .

\section{Findings and Discussion}

In the research conducted between 2017-2018, there are intermedia of lavandin L.x in the ecological conditions of Diyarbakir. The adaptation, flowering stage, yield and harvesting period of the Supera variety were investigated in vivo.

\subsection{Adaptation of the planted Supera 'lavandin variety seedlings and flowering phase}

In the research, irrigation and maintenance operations were carried out continuously after the planting phase of the 'Supera' lavandin type fidelites taken from Eğridir district, Eğridir Fruit Research Center in Isparta province. There is intermedia L.x. The adaptation of the Super A plant is almost ensured. The first weekly plantings of the fidelites planted in May, June, July, August, September and October were observed, and the numbers of plants adapted to flowering and flowering were determined (Table 3).

Table 3.The results of the adaptation and flowering stages of the planted Supera 'lavandin variety seedlings

\begin{tabular}{|c|c|c|}
\hline MONTHS & LIVING PLANT NUMBER(\%) & $\begin{array}{c}\text { NUMBER OF BLOOMING } \\
\text { PLANTS }\end{array}$ \\
\hline MAY & 45 & 0.0 \\
\hline JUNE & 55 & 1155 \\
\hline JULY & 60 & 1230 \\
\hline AUGUST & 63 & 1323 \\
\hline SEPTEMBER & 63 & 1323 \\
\hline OCTOBER & 63 & 1232 \\
\hline
\end{tabular}

*The data were taken at the end of each month.

\subsection{There is intermedia L.x. The yield and harvesting period of Super A 'lavandin plant}

Lavender reaches the full bloom cycle in July, with varying species and varieties, climate and soil conditions, altitude and direction, and is harvested during this period. There is intermedia L.x. The adaptation of Supera plant in Diyarbakir conditions and harvesting after the flower period reached the end of June. Sowed grass knives are used in the harvest of the plant. However, the yield was low because the yield was low in the first year. [9], reported that first year yield was not obtained in 
lavender cultivation and that yield was started to be obtained from second year. This supports the quality of our work.

In recent years, harvesters have been harvested with gasoline hedge mowers. Machine harvesting saves labor and time.

The harvested flowers were laid out in a shaded environment at a thickness that would not create an escape. Dried lavender flowers with the handle were separated by hand from the stems and the number of flowers on the surface was noted (Table 4).

Table 4. There is intermedia L.x. The yield and harvest period results of the Super A 'lavandin plant

\begin{tabular}{|c|c|c|}
\hline MONTHS & NUMBER OF FLOWER & $\begin{array}{c}\text { NUMBER OF FLOWER AT } \\
\text { HARVEST TIME }\end{array}$ \\
\hline MAY & 0.0 & 0.0 \\
\hline JUNE & 2310 & 0.0 \\
\hline JULY & 2460 & 18450 \\
\hline AUGUST & 2646 & 0.0 \\
\hline SEPTEMBER & 2646 & 0.0 \\
\hline OCTOBER & 2646 & 12320 \\
\hline
\end{tabular}

*The data were taken at the end of each month.

\section{Results}

In recent years, agriculture of medicinal and aromatic plants, which are used for pharmaceuticals, cosmetics, perfumery, industry and food and have important share in exports, is becoming increasingly widespread. In medical plants, quality concept is more important than efficiency. Because the plants that are actually used and effective in these plants are the substances in the composition of that plant. Therefore, the scientific researches on quality improvement enhancing techniques have been increased and significant developments have been recorded.

Production and reproduction of the lavender plant as it is in other aromatic plants is carried out in two main ways, generative and vegetative. However, because of the infertility of the 'Super A' lavandin variety of Lavandula $\mathrm{x}$ intermedia species and the lack of seeds, vegetative propagation and fleece obtained from shoot steels were used. A total of 1552 seedlings were planted from the 'Super A' lavandin variety of Lavandula $\mathrm{x}$ intermedia line, from the field of Dicle University Medical and Aromatic Plants Application and Research Center to the field of 4.2 and April 6, 2017 in the field. Observations during the months of May, June, July, August, September and October of the survey showed that some of the fidelites had died. The survival of the remaining fidelites continued and the adaptation rate was $63 \%$ in the trial area. Flowering The flowers were harvested 3 times between June and October, which began in June. At the end of this study; 21-33 cm long plants were obtained. This results in light of lavender farm in Turkey, was concluded in Diyarbakir to do outside of Isparta.

In the next step, we will work on the production of the herbal materials obtained from our work in steel, in vitro and in vitro, and on the determination of their medical and aromatic contents. 


\section{Acknowledgement}

We would like to express our appreciation to the Dicle University Scientific Research Project Commission, which supported this study (DUBAP/TARIM-MYO. 17.001).

\section{Referances}

[1] Anonymous., (http://www.gardenguides.com) 2011.

[2] Bajaj, Y. P. S., Furmanowa, M., Olszowska, O., Biotechnology of the micropropagation of medicinal and aromatic plants. Biotechnology in Agriculture and Forestry, 4: 60-103. 1988.

[3] Bajaj (ed) Biotechnology in Agriculture and Forestry, 15: 283-310, Medicinal and Aromatic lants III, Springer-Verlag, Berlin, 1988.

[4] Baydar, H., Medical, aromatic and pleasure crops science and technology, (Extended II edition). Süleyman Demirel University (Faculty of Agriculture), Vol. 51 pp. 205-212. 2007.

[5] Baydar H., Erbaş, S., Effects of harvest time and drying on essential oil properties in lavandin (Lavandula $x$ intermedia Emeric ex Loisel.), I. International Medicinal and Aromatic Plants Conference on Culinary Herbs, 29 April - 4 May 2007, Antalya-Turkey, 2007.

[6] Baydar, H., Lavender and Volatile Oil Technology. SDU Faculty of Agriculture Graduate Course Note (Unpublished), 2010a.

[7] Baydar, H., Beyoglu should go to lavender Isparta. Agriculture journal 15: 62-63, 2010b

[8] Beetham J., Entwistle T., The Cultivated Lavenders. Royal Botanic Gardens, 1982

[9] Ceylan, A., Vömel, A., Kaya, N., Çelik, N., Nigdeli, E., Research on the yield and quality effects of plant density in lavanta. Ege University Agriculture Faculty journal, 25 (2): 135-145, 1988

[10] Ceylan, A., Medical Plants-II (Essential Oil Plants). Ege University Agriculture Faculty Publications No: 481, İzmir,1996

[11] Chawla, H. S., Introduction to Plant Biotechnology, 3rd ed. Science Publishers, Enfield, NH, USA, 2009.

[12] Güner, A., Özhatay, N., Ekim, T and Baser, K.H.C., Flora of Turkey and East Aegean Islands. Supplement II. Edinburgh Univ, Vol. 11, 2000, pp. 618-619.

[13] Hickey, M and King, C., Common Families of Flowering Plants. Cambridge Univ, pp 119$127,1997$.

[14] Kan, Y., Arslan, N. Altun, L and Eagle, M., The economic importance of the culture of medicinal and aromatic plants in Turkey. 15. The meeting of herbal medicines raw materials conference, vol. 3, 2006, pp. 213-219.

[15] Lis-Balchin, M., Lavender. Taylor \& amp; Francis, 2002, pp. 283.

[16] Mokhtarzadeh, S., Lavandula angustifolia Miller Subsp. angustifolia Miller and L. stoechas L. Subsp. Optimization of tissue and gene transfer studies in L. stoechas plants. Ankara University Graduate School of Natural and Applied Sciences Field Crops Department Doctorate Thesis, 114 pp, 2011

[17] Nogueira, J. M. F., Romano, A., Essential oils from micropropagated plants of Lavandula viridis. I Phytochem. Anal., 13: 4-7, 2002

[18] Ozkum, D., Oregano minutiflorum and Sideritis stricta research on reproduction through tissue culture. Hacettepe University, Graduate School of Natural and Applied Sciences, Department of Biology, Doctorate Thesis, Ankara, 2006 
[19] Pierik, R.L.M., In vitro Culture of Higer Plants. Martinus Nijh of Publishers, Dordrect, p. 344, 1987

[20] Tucker, A.O., Lavender, spike, and lavandin. The Herbarist. 51:44-50, 1985

[21] Zuzarte, M. R., Dinis, A. M., Ligia, C. C., Salgueiro, R., Canhoto, J. M., Trichomes, essential oils and in vitro propagation of Lavandula pedunculata (Lamiaceae). Industrial Crops and Products, 32 (3): 580-587, 2010

[22] Weiss, E.A., Essential Oil Crops. CAB International, New York, USA, 1997. 